\section{MOLÁRNÍ MNOŽSTVÍ VODY}

\section{Marek Mateják, Jiří Kofránek}

\section{Abstrakt}

Při modelování tělesných tekutin pomocí fyzikální chemie jsme narazili na rozpor. Vycházeli jsme přitom z mylného předpokladu, že molární množství vody ve vodném roztoku je molárním množstvím molekul $\mathrm{H}_{2} \mathrm{O}$ (hmotnost dělená hmotností jedné molekuly $\mathrm{H}_{2} \mathrm{O}$ ). V jednom kilogramu čisté vody jsme tedy počítali s 55.508 mol vody, protože molární hmotnost $\mathrm{H}_{2} \mathrm{O}$ je $18.01528 \mathrm{~g} / \mathrm{mol}$. Při počítání molárních frakcí jako molární množství látky dělené celkovým molárním množstvím roztoku jsme tak dostávali numericky úplně jiné hodnoty než při molalitách nebo při molaritách. Přitom podle teorie by měly být tyto hodnoty zastupitelné. Ukázalo se však, že použití těchto hodnot ve výpočtech rozpustnosti plynů ve vodních roztocích nám vykazovaly právě chybu cca $55 \mathrm{~mol} / \mathrm{kg}$. Podobné chyby se začaly vykazovat pro chemické procesy s různým počtem reaktantů a produktů (při stejném počtu se chyba algebraicky anuluje). Je tedy skutečně molalita vody cca $55 \mathrm{~mol} / \mathrm{kg}$ ? Ne. Voda totiž mezi sebou vytváří vazby, které shlukují více molekul $\mathrm{H}_{2} \mathrm{O}$ do větších částic. $Z$ požadovaného molárního množství vody jsme odvodili disociační konstantu i entalpii této vazby tak, aby výsledky byly kompatibilní s daty z National Institute of Standards and Technology (NIST) i s daty formačních energií jednotlivých substancí. Použitím těchto konstant je zpětně možné odvodit molární množství vody ve vodních roztocích a následně dělat výpočty přes molární frakce, jejichž výsledky se začínají shodovat $\mathrm{s}$ naměřenými a publikovanými experimenty.

\section{1 Úvod}

Ve fyzikální chemii se často mluví jenom o hodně zředěných roztocích [1], zatímco u tělesných tekutin ve fyziologii to neplatí. Např́klad intracelulární tekutina má jenom cca. $70 \%$ vody. Běžné výpočty zde přestávají platit, protože posun od standardního stavu vodného roztoku je tak výrazný, že je potřeba rozšírení teorie fyzikální chemie i pro tyto podmínky. Jedním z našich pokusů je právě rozšíření pomocí hypotéz o molárním množství vody, kterým nahrazujeme konstanty standardní molality a standardní molarity.

Náš výzkum molárního množství u vodných roztoků začal nevědomě již v dubnu 2015 publikovanou otázkou na webu www.researchgate.net: „Jaká je koncentrace hydronií $\left(\mathrm{H}_{3} \mathrm{O}^{+}\right)$nebo volných protonů $\left(H^{+}\right)$jako ekvivalent $\mathrm{pH}=7.4$ ve vodném roztoku?". Přestože tato otázka na této mezinárodní vědecké síti měla cca 20 tisíc zhlédnutí, 38 veřejných odpovědí, a následovaly i další soukromé komunikace, její jednoznačná odpověd' zde nebyla nalezena. Jeden způsob kalkulace výsledku z disociace vody totiž ukazoval na molární frakci $10^{-7.4} \mathrm{~mol} / \mathrm{mol}$. Prímo z definice $\mathrm{pH}$ by to však měla být molalita $10^{-7.4} \mathrm{~mol} / \mathrm{kg}$. Právě rozpor těchto fyzikálních jednotek již tenkrát směřoval k tomu, že obojí může být pravda jenom tehdy, když v daných podmínkách $v$ jednom kilogramu vody bude právě jeden mol všech částic.

Počítání kyselosti $(\mathrm{pH})$ krve a jiných tělesných tekutin v rámci acidobazické rovnováhy se naše laboratoř pritom zabývá již celou řadu let. Až integrací více modelů do jednoho celku se vše začíná formalizovat takovým způsobem, že je nutné vyřešit všechny redundantní i protichůdné vztahy tak aby výsledný matematický model jednoznačně definoval průběh popisovaných proměnných v čase. Tato formalizace však vyžaduje propojení ideálně až na úroveň základní teorie jako je fyzika nebo fyzikální chemie [2]. Použití fyzikální chemie pro simulace ve fyziologii nebo $v$ medicíně není dnes př́liš rozšířeno. Výpočty $v$ těchto oborech nadále zůstávají převážně u empirických vztahů nebo u základní fyziky, často i s velkou tolerancí chyby. A to i naproti tomu, že moderní výpočetní technika si s robustními fyzikálními soustavami rovnic umí poradit jak algebraicky, tak numericky. Ze zkušeností s empirickými rovnicemi by se však mohlo zdát, že velké množství rovnic bude spojené $s$ velkým množstvím neznámých parametrů. Při správném použití fyzikálních vztahů to ale nemusí být pravda, protože fyzika je založená na eliminaci „neznámých parametrư" či v extrémním případě i dokonce „neznámých konstant". Tuto eliminaci dělá právě pomocí vztahů, kterými tyto hodnoty definuje. Proto je teoreticky možné vytvářet i velmi složité a komplexní fyzikálně-matematické modely, které potřebují jenom malé množství dobře známých (tj. odvoditelných nebo měřitelných) parametrů a konstant.

Při tvorbě našich modelů fyziologie člověka [3-6] se pokoušíme detailně popsat tělesné tekutiny: krevní plazmu, intersticiální mezibuněčnou tekutinu, intracelulární tekutinu, mozkomíšní mok, moč aj. Při popisu těchto vodných roztoků se zajímáme o vztahy jednotlivých substancí, a jejich procesů. Tyto procesy úzce souvisí s teplem, nábojem, kyselostí, rozpustností plynu ve vodě a jinými vlastnostmi, které popisuje právě fyzikální chemie. $V$ roce 2015 jsme implementovali Modelikovou knihovnu pro fyzikální chemii [7], kterou používáme pro výpočty těchto procesů ve vodných roztocích nebo i mezi nimi. Tehdy tato softwarová knihovna obsahovala komponenty pro ekvilibrium chemických procesů jako jsou chemické reakce, difuze, rozpustnost plynů v roztocích, přenos elektronů mezi různými prostředími, Donnanovy rovnováhy na membráně dle Nernstových vztahů, atd.

Jednou z dalších otázek plynoucích z implementace této softwarové knihovny byla nezbytná korekce při vyjádření rozpustnosti plynů ve vodě. Vypočtená hodnota Henryho konstanty pro rozpustnost plynu ve vodě totiž nebyla stejná jako naměřená hodnota publikovaná pomocí tabulek National Institute of Standards and Technology (NIST). Tento problém byl v roce 2015 detailně popsaný v disertační práci [8] na straně 38. Již v té době jsme porovnávali Henryho konstanty pro různé plyny s jejich odvozenými hodnotami. Zjistili jsme, že koeficient, o který se hodnoty liší, je pro každý plyn stejný. Tehdy jsme však nevěděli proč. Dalším zkoumáním vlastností tekuté vody jsme zjistili, že vysvětlení může být poměrně jednoduché. Výpočty jsou totiž závislé na molární frakci daného plynu ve vodě. Molární frakce látky je poměr molárního množství (počtu částic) dané látky k molárnímu množství všech látek v daném roztoku. Netrvalo dlouho a uvědomili jsme si, že pokud upravíme molární množství vody, tak je možné dostat shodu s měřenými hodnotami rozpuštěného plynu. Molární množství vody totiž není rovno molárnímu množství molekul $\mathrm{H}_{2} \mathrm{O}$. Molekuly $\mathrm{H}_{2} \mathrm{O}$ mezi sebou dělají dynamicky slabé vodíkové můstky [9]. Tyto vazby $v$ tekuté vodě vytvářejí shluky molekul $\mathrm{H}_{2} \mathrm{O}$, přičemž je nutné každý takovýto shluk $v$ daném časovém momentě považovat na jednu částici.

\section{Metody}

Jako možnou hypotézu jsme si zvolili následující tvrzení: „V tekuté vodě se molekuly $\mathrm{H}_{2} \mathrm{O}$ navzájem vážou do klastrů vazbami tak, že tyto vazby nevytvárejí cykly a každá tato vazba má stejné vlastnosti."

Cyklus vazeb je spojení dvou molekul $\mathrm{H}_{2} \mathrm{O}$, které jsou již součástí jednoho klastru. Předpoklad, že vazby nevytvářejí cykly je poměrně silný, a v mnohých článcích se naopak vyskytují struktury, kde tyto cykly existují. Naproti tomu jsme zůstali při představě, že je mnohem pravděpodobnější, že vazby mezi jednotlivými klastry (s libovolným počtem molekul vody) jsou stejné jako mezi jednotlivými molekulami vody a jsou na sobě nezávislé.

Pokud jsou vazby na sobě nezávislé, pak mají i stejné vlast- 


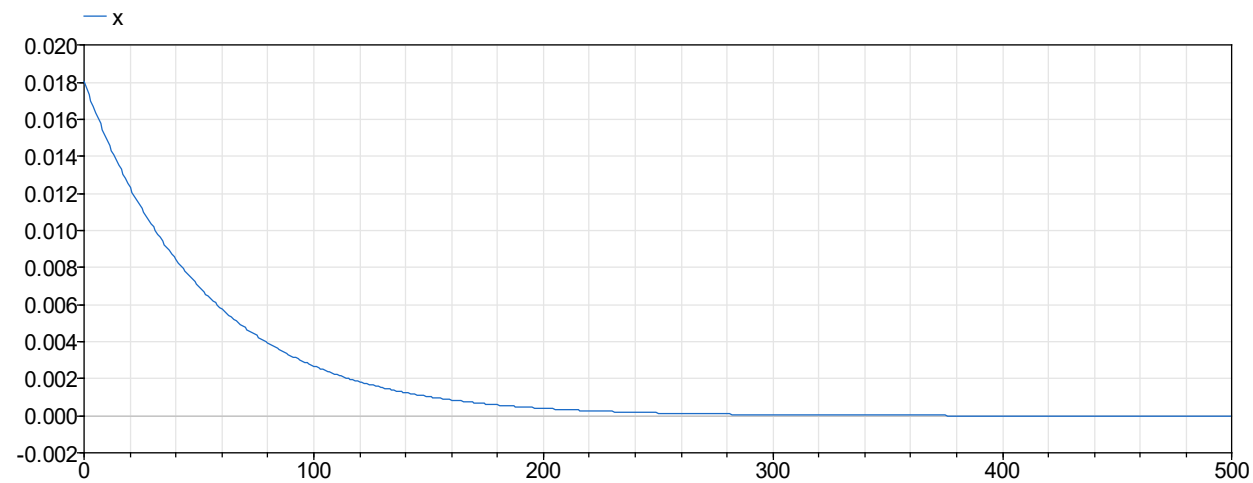

Obrázek 1 - Rozložení molárních frakcí podle počtu molekul H2O v klastru. Četnost klastru dané velikosti exponenciálně klesá s jeho velikostí. Čím většl klastr tím má menši koncentraci.

nosti jako je entalpie a entropie vodíkových vazeb mezi molekulami $\mathrm{H}_{2} \mathrm{O}$. Tedy disociační konstanta $(\mathrm{K})$ při spojení dvou klastrů je stejná jako disociační konstanta mezi dvěma volnými molekulami $\mathrm{H}_{2} \mathrm{O}$.

Na základě těchto tvrzení jsme sestrojili matematický model, který přesně odvozuje molární frakce $\left(x_{i}\right)$ množin klastrů $z$ určitého počtu molekul $\mathrm{H}_{2} \mathrm{O}$ (i). Přitom není vůbec důležité, jak dlouho tento stav konkrétních klastrů vydrží, protože počet jednotlivých klastrů zůstává stejný i když se vazby rychle dynamicky mění.

$$
\begin{gathered}
\mathrm{H}_{2} \mathrm{O}+\mathrm{H}_{2} \mathrm{O}<->\left(\mathrm{H}_{2} \mathrm{O}\right)_{2} \mathrm{~K}=x_{1} * x_{1} / x_{2} \\
\mathrm{H}_{2} \mathrm{O}+\left(\mathrm{H}_{2} \mathrm{O}\right)_{\mathrm{i}-1}<->\left(\mathrm{H}_{2} \mathrm{O}\right)_{\mathrm{i}} \mathrm{K}=x_{1} * x_{\mathrm{i}-1} / x_{\mathrm{i}}
\end{gathered}
$$

Tato chemická reakce definuje geometrickou radu pro $x_{i}=x_{i-1}$ ${ }^{*} \mathrm{x}_{1}{ }^{*} \mathrm{~K}$, kterou je možné zapsat také jako $\mathrm{x}_{\mathrm{i}}=\mathrm{x}_{1}{ }^{*}\left(\mathrm{x}_{1}{ }^{*} \mathrm{~K}\right)^{\mathrm{i}-1}$. Součet všech molárních frakcí v čisté vodě pokud zanedbáme $\mathrm{OH}^{-}$a $\mathrm{H}^{+}$ ionty kterých je $10^{-7} \mathrm{~mol} / \mathrm{mol}$ jako suma $x_{i}$ přes i od 1 až do nekonečna je roven 1.

$$
1=\sum_{i=1}^{\infty} x_{1} \cdot\left(x_{1} \cdot K\right)^{i-1}=\frac{x_{1}}{\left(1-x_{1} \cdot K\right)} \quad \begin{array}{r}
\text { Součet všech } \\
\text { molárních frakcí }
\end{array}
$$

Za předpokladu, že $\mathrm{x} 1^{*} \mathrm{~K}$ je kladný a menší jako 1 , je možné použít vztah pro geometrickou posloupnost

$$
\sum_{k=0}^{\infty} a r^{k}=\frac{a}{(1-r)}
$$

Velikost jednotlivých členů se zde exponenciálně zmenšuje (Obr. 1) a proto je celkový součet této nekonečné řady konečný.

$V$ jednom kilogramu čisté vody je $1 / \mathrm{MM}(55.508 \mathrm{~mol} / \mathrm{kg}$, kde MM je molární hmotnost $\mathrm{H}_{2} \mathrm{O}$ ) mol-u molekul $\mathrm{H}_{2} \mathrm{O}$ a pritom počet částic je dle naměřených dat $\mathrm{N}$ :

$$
\begin{array}{|c|c|}
\hline \frac{1}{M M}=\sum_{i=1}^{\infty} i \cdot N \cdot x_{1} \cdot\left(x_{1} \cdot K\right)^{i-1}=\frac{N \cdot x_{1}}{\left(1-x_{1} \cdot K\right)^{2}} & \begin{array}{c}
\text { Počet molekul } \mathrm{H}_{2} \mathrm{O} \\
\text { v } 1 \text { kg vody }
\end{array} \\
\hline
\end{array}
$$

Máme tedy $\mathrm{k}$ dispozici dvě rovnice pro dvě neznámé, co umožňuje jejich př́mé odvození:

\begin{tabular}{|l|c|}
\hline$x_{1}=M M \cdot N$ & $\begin{array}{c}\text { Molární frakce volné } \\
\text { molekuly } \mathrm{H}_{2} \mathrm{O}\end{array}$ \\
\hline$K=\frac{1}{M M \cdot N}-1$ & $\begin{array}{c}\text { Disociační konstanta } \\
\text { vodíkové vazby vody }\end{array}$ \\
\hline
\end{tabular}

Na závěr stačí ověřit, že součin $\mathrm{x}_{1}{ }^{*} \mathrm{~K}$ je menší jako 1 . Počet klastrů (N) musí být menší jako počet molekul $\mathrm{H}_{2} \mathrm{O}(1 / \mathrm{MM})$ a proto $M M^{*} \mathrm{~N}<1$ a proto i součin $\mathrm{x}_{1}{ }^{*} \mathrm{~K}=1-\mathrm{MM}^{*} \mathrm{~N}<1$. Použití výpočtu geometrické řady je tedy oprávněné pro každou možnou naměřenou hodnotu $\mathrm{N}$.

Jednou z možností jak odhadovat počet částic vody (N) je mě- ření rozpustnosti plynů (A) ve vodě a následné srovnání s energetickým ekvilibriem tohoto chemického procesu. Z rovnováhy chemických potenciálů plynné a rozpuštěné látky $A$ je možné odvodit vztah mezi rozdílem formačních Gibbsových energií $\left(\Delta_{\text {dis }} G^{\circ}\right)$ a Henryho koeficientem $(\mathrm{kH})$ :

$$
k H=\frac{a_{A(a q)}}{a_{A(g)}}=e^{-\frac{\Delta_{d i s} G^{o}}{(R \cdot T)}} \quad \begin{gathered}
\text { Henryho koeficient pro } \\
\text { molární frakce }
\end{gathered}
$$

Z tabulkových hodnot formačních energií pro plynou $\left(\Delta_{f} G^{o-}\right.$ $\left.{ }_{A(g)}\right)$ i rozpuštěnou látku ve vodě $\left(\Delta_{f} G_{A(a q)}^{o}\right)$ je tedy možné určit hodnotu $\Delta_{\text {dis }} G^{o}=\Delta_{f} G_{A(a q)}^{o}-\Delta_{f} G_{A(g)}^{o}$. Zároveñ je možné změřit molární frakci látky $\mathrm{A}$ v plynu $\left(a_{A(g)}\right)$ i molární množství látky $\mathrm{A}$, která se rozpustila ve vodě $\left(n_{A(a q)}\right)$. Pak Ize $\mathrm{N}$ vyjádřit ze vztahu:

\begin{tabular}{|l|c|}
\hline$N=\frac{n_{A(a q)}}{a_{A(g)}} e^{\frac{\left(\Delta_{f} G_{A(a q)}^{o}-\Delta_{f} G_{A(g)}^{o}\right)}{(R \cdot T)}}$ & $\begin{array}{c}\text { Počet částic } \\
\text { v } 1 \text { kg čisté vody }\end{array}$ \\
\hline$N=\frac{n_{A(d)}}{a_{A(g)} \bullet H_{(a q)}}$ & $\begin{array}{c}\text { Počet částic } \\
\text { v } 1 \text { kg vodního roztoku }\end{array}$ \\
\hline
\end{tabular}

\section{Výsledky}

První odhad počtu částic vody jednom kilogramu čisté vody je 1 mol (standardní molalita). Pro tuto hodnotu je možné vyjádřit

Dle NIST (National Institute of Standard and Technology, viz https://www.nist.gov/ je Henryho konstanta pro rozpustnost CO ve vodě rovna $0.035 \mathrm{~mol} / \mathrm{kg} / \mathrm{bar} v$ čisté vodě, $\mathrm{kde} 1 \mathrm{~kg}$ vody obsahuje 1 mol všech částic. V intracelulární tekutině je při parciálním tlaku $\mathrm{pCO}_{2}=40 \mathrm{mmHg}=40 / 760$ bar naměřena koncentrace volně rozpuštěného $\mathrm{CO}_{2}$ jako $1.24 \mathrm{mmol} / \mathrm{L}$. Celkový počet částic intracelulární tekutiny je tedy $0.67 \mathrm{~mol} / \mathrm{L}$. Co zhruba potvrzuje i měření objemového podílu vody nebo měření rozpustnosti pro $\mathrm{O}_{2}$ nebo i isoosmolarita vyjádřena v součtu molárních frakcích pasivně nepropustných látek.

Tyto a mnohé další fyziologické výpočty pak podporujeme pomocí softwarové knihovny určené pro fyziologii [10-13].

Podobným zpưsobem je možné vyjádřit molární hustotu všech tělesných tekutin a následně přejít na počítání přes molární frakce místo molalit nebo molarit [14]. Počítání přes molární frakce je ve fyzikální chemii přímo propojené na výpočet energií a elektrochemických potenciálů. Proto je pak možné jednoduše vyjádřit koncové stavy elementárních procesů jako vyrovnání elektrochemických potenciálů. To umožní využití fyzikální chemie na odvozování disociačních konstant, Henryho koeficientů, elektrických potenciálů, Nernstových napětí, Donanových rovnováh na buněčné mebráně, osmolarit a jiných elektrochemických dějů. 


\section{Diskuse}

Bohužel, mnoho knih týkajících se fyzikální chemie klade mezi molaritou, molalitou a molární frakcí ve vodních roztocích rovnost (a to bud' př́mo nebo přes aktivity nebo přes chemický potenciál). Přitom jsou si sami vědomi, že tato rovnost platí jenom za specifických podmínek a při nízké koncentraci rozpuštěných látek. Aby to celé bylo $v$ pořádku i z hlediska fyzikálních jednotek, tak byli zavedeny konstanty "standardní molalita" a "standardní molarita", které jim převedou moly na kilogramy nebo na litry. Na neštěstí se tyto konstanty staly i součástí definic. Jednou z nich je i definice $\mathrm{pH}$. Dnešní měření $\mathrm{pH}$ přes vodíkovou elektrodu však neměří molalitu, nýbrž elektrické napětí na oxidačně-redukčních reakcích a tedy aktivitu vodíkových iontů. Přitom přepočet na molalitu aktivity těchto kladně nabitých částic vody by měl záviset na molární hustotě. Výsledkem je, že teoretická bilance, používající aktuální definici pH, se nemůže plně shodovat $s$ měřeními $v$ prostředích jako je intracelulární tekutina (kde zhruba neplatí 1 všech mol částic na 1 kg rozpouštědla nebo na $1 \mathrm{~L}$ roztoku). Z principu totiž aktuální definice $\mathrm{pH}$ funguje tam, kde funguje "standardní molalita“, tj. $v$ roztocích kde platí celková molární hustota 1 mol všech látek na 1 kg rozpouštědla.

Naše představa o vodě vychází pouze z makroskopických vlastností, které nás zajímají. Přestože model odvozuje početnosti jednotlivých klastrů vody, tak pro nás je podstatný jenom jejich celkový počet. Naše hypotéza tedy byla potvrzena jenom částečně a na její plné potvrzení jsou nutné další měření a experimenty již molekulárních vlastností $\mathrm{H}_{2} \mathrm{O}$ a jejich vodíkových vazeb.

Kdybychom např́klad polevili z tohoto predpokladu, a uvnitř jednoho klastru povolíme další cyklické vodíkové vazby, tak je možné výpočet přeformulovat na molární frakci klastru jako $\mathbf{x}_{i, j}$ $=\mathbf{x}_{1}{ }^{*}\left(\mathbf{x}_{1}{ }^{*} \mathbf{K}\right)^{\mathrm{i}-1}{ }^{*} \mathbf{K}_{\text {(int) }}{ }^{j}$ za předpokladu, že všechny interní vazby by měli stejnou disociační konstantu $\mathrm{K}_{\text {(int) }}$. Přidaný index $\mathrm{j}$ tu vyjadřuje počet interních vazeb, které v pưvodním modelu chybí. Při sumaci těchto frakcí je však nutné vynechávat první členy, protože tyto interní cyklické vazby mohou existovat až od určité velikosti klastru. Například nejmenší klastr s jednou interní vazbou musí mít minimálně 4 molekuly $\mathrm{H}_{2} \mathrm{O}$, se dvěma 6 , se třemi 8 , se čtyřmi 9 atd. Tyto komplexnosti však pro nás přicházejí v úvahu až v momentu, když budeme mít protichůdná data vyžadující rozšíření teorie o další stupeň volnosti. Zatím si po vzoru Occamovy břitvy vystačíme s modelem jednodušším, kde $j=0$.

\section{Závěr}

Voda mezi sebou vytváří vazby, které shlukují více molekul $\mathrm{H}_{2} \mathrm{O}$ do větších částic. Předpokládáme, že v tekuté vodě se molekuly $\mathrm{H}_{2} \mathrm{O}$ navzájem vážou do klastrů vazbami tak, že tyto vazby nevytvářejí cykly a každá tato vazba má stejné vlastnosti jako je entalpie a entropie vodíkových vazeb mezi molekulami $\mathrm{H}_{2} \mathrm{O}$. Pak disociační konstanta při spojení dvou klastrů je stejná jako disociační konstanta mezi dvěma volnými molekulami $\mathrm{H}_{2} \mathrm{O}$. Na základě těchto předpokladů jsme sestrojili matematický model, který přesně odvozuje molární frakce množin klastrů z určitého počtu molekul $\mathrm{H}_{2} \mathrm{O}$. Přitom není vůbec podstatné, jak dlouho tento stav konkrétních klastrů vydrží, protože počet jednotlivých klastrů $v$ ustáleném stavu zůstává stejný i když se vazby rychle dynamicky mění.

Z požadovaného molárního množství vody jsme odvodili disociační konstantu i entalpii vodíkových vazeb mezi molekulami $\mathrm{H}_{2} \mathrm{O}$ tak, abychom byli kompatibilní s daty z National Institute of Standards and Technology (NIST) i s daty formačních energií jednotlivých substancí. Použitím těchto konstant je zpětně možné odvodit molární množství vody ve vodních roztocích a následně dělat výpočty přes molární frakce, jejichž výsledky se začínají shodovat s publikovanými experimenty.

\section{Literatura}

[1.] José J. C. Teixeira-Dias. "Molecular Physical Chemistry: A Computer-based Approach using Mathematica ${ }^{\circledR}$ and Gaussian", Springer, 2017

[2.] M. Mateják, „Formalization of Integrative Physiology", PhD Thesis, Charles University in Prague, 2015.

[3.] Mateják, Marek; Kofránek, Jiři; „Rozsáhlý model fyziologických regulací v Modelice", MEDSOFT 2010. Praha: Agentura Action M, Praha 2010, str. 66-80. ISSN 180381115,2010

[4.] Mateják, Marek; Kofránek, Jiří „HumMod-Golem Edition-Rozsáhlý model fyziologických systém", Medsoft 2011, 182-196, 2011

[5.] Kofránek, Jirí; Mateják, Marek; Privitzer, Pavol; Tribula, Martin; Kulhánek, Tomás; Silar, Jan; Pecinovský, Rudolf; "HumMod-Golem Edition: large scale model of integrative physiology for virtual patient simulators", Proceedings of the International Conference on Modeling, Simulation and Visualization Methods (MSV), 1, 2013

[6.] Mateják, Marek; Kofránek, Jiř́i "Physiomodel-an integrative physiology in Modelica", 2015, 37th annual international conference of the IEEE Engineering in Medicine and Biology Society (EMBC), 1464-1467, 2015, IEEE

[7.] M. Mateják, M. Tribula, F. Ježek, a J. Kofránek, "Free Modelica Library of Chemical and Electrochemical Processes", in 11th International Modelica Conference, Versailles, France, 2015, roč. 118, s. 359-366.

[8.] MATEJÁK, MAREK. Formalization of Integrative Physiology.Prague, 2015. 115, 3, 1 CD. Dissertation thesis. Charles University in Prague, First Faculty of Medicine, Institute of Pathological Physiology. Supervisor Doc. MUDr. Jiří Kofránek CSc.

[9.] Luzar, A., \& Chandler, D. "Hydrogen-bond kinetics in liquid water Nature", 379(6560), 55-57. doi:10.1038/379055a0, 1996

[10.] M. Mateják, T. Kulhánek, J. Šilar, P. Privitzer, F. Ježek, a J. Kofránek, "Physiolibrary-Modelica library for physiology", in Proceedings of the 10 th International Modelica Conference; March 10-12; 2014; Lund; Sweden, 2014, s. 499-505.

[11.] Mateják, Marek; „PHYSIOLOGY IN MODELICA“, MEFANET Journal, 2014

[12.] Mateják, Marek; Kulhánek, Tomáš; Matoušek, Stanislav; „Adair-based hemoglobin equilibrium with oxygen, carbon dioxide and hydrogen ion activity", Scandinavian Journal of Clinical \& Laboratory Investigation, 2015, Informa Healthcare

[13.] Mateják, Marek; Ježek, Filip; Tribula, Martin; Kofránek, Jiří: „Physiolibrary 2.3-An Intuitive Tool for Integrative Physiology",IFAC-PapersOnLine, 48, 1, 699-700, 2015, Elsevier

[14.] Mateják, Marek, "Modelování tělesných tekutin v jazyku Modelica”, Medsoft 2019, 103-112, 2019 


\section{Kontakt}

Mgr. Marek Mateják, Ph.D.

Oddělení biokybernetiky

Ústav patologické fyziologie

1. LF UK

e-mail:matejak.marek@gmail.com

tel: +420 776301395

doc. MUDr. Jiří Kofránek, CSc.

Oddělení biokybernetiky

Ústav patologické fyziologie

1. LF UK

e-mail:kofranek@gmail.com

tel: +420777686868 